\title{
Immunohistochemical Localization of Brain-Gut Hormones in Gastric Garcinoma with Relation to Argyrophil Cells
}

\author{
Shuji Yamada, Nobuaki Sasano and Takuji Nakamura* \\ Department of Pathology, Tohoku University School of \\ Medicine, Sendai 980, and *Department of Surgery, Gunma \\ University School of Medicine, Maebashi 371
}

\begin{abstract}
Yamada, S., Sasano, N. and Nakamura, T. Immunohistochemical Localization of Brain-Gut Hormones in Gastric Carcinoma with Relation to Argyrophil Cells. Tohoku J. exp. Med., 1984, 143 (1), 1-15 — A total of 87 surgical cases of gastric carcinoma including 3 carcinoid tumors were investigated with the methods of silver reaction and immunoperoxidase stain for 8 different brain-gut hormones. Argyrophil (AP) cells were demonstrated in 38 cases (44\%), argentaffin (AF) cells in $18(21 \%)$ and endocrine cells in $13(14 \%)$. The occurrence of endocrine cells had no relation with histological types. Glicentin cells were demonstrated in 10 cases, somatostatin in 7 , motilin in $3, \beta$-endorphin in 2 and gastrin in one. Endocrine cells appeared generally in small numbers except one carcinoid tumor which had numerous somatostatin cells. No single cell positive for more than two kinds of hormones could be demonstrated. Two undifferentiated carcinomas looking like carcinoid tumors had argyrophil cells and endocrine cells of either somatostatin or $\beta$-endorphin. These results suggest that carcinoid-like carcinoma or endocrine cell carcinoma may lie on the intermediate state between carcinoma and carcinoid tumor.— gastric carcinoma; carcinoid tumor; argyrophil cell ; endocrine cell ; brain-gut hormone
\end{abstract}

Argyrophil (AP) and argentaffin (AF) cells in gastric carcinoma have repeatedly been documented by several investigators. (Hamperl 1927; Azzopardi and Pollock 1963; Soga et al. 1971; Kubo and Watanabe 1971; Watanabe 1972; Tahara et al. 1975). If these cells are identical to AP and AF cells in the normal gastrointestinal mucosa, they may produce amines and/or polypeptide hormones.

Immunohistochemical demonstration of brain-gut hormones in gastric carcinoma was successful first for gastrin (Tahara et al. 1975, 1980 ; Nagata 1977 ; Prade et al. 1982). Furthermore, Tahara et al. (1982) demonstrated somatostatin in argyrophil cells in early gastric carcinoma and somatostatin and glucagon in scirrhous argyrophil cell carcinoma of the stomach. Endocrine cells containing

Received for publication, August 26, 1983.

Address for reprints: Nobuaki Sasano, M.D., Department of Pathology, Tohoku University School of Medicine, 2-1 Seiryomachi, Sendai 980, Japan. 
polypeptide hormones have been demonstrated in gastric carcinoid tumors (Wilander et al. 1979 ; Dayal et al. 1980).

The present paper deals with the immunohistochemical localization of several kinds of brain-gut hormones in carcinoma and carcinoid tumors of the stomach in relation to AP and AF cells. Discussion will be focused on the findings of endocrine cells of neoplastic and/or non-neoplastic origin appeared in gastric carcinoma.

\section{Materials and Methods}

Materials were 87 surgical cases of gastric carcinoma, consisting of 13 early carcinomas confined to the submucosal layer, 71 advanced carcinomas involving up to the proper muscle layer and deeper and 3 carcinoid tumors. They were randomly collected from the files in the period from 1978 to 1981 of Department of Pathology, Tohoku University School of Medicine; the First Department of Surgery, Gunma University School of Medicine; and Departments of Surgery, National Sendai Hospital and Sendai City Hospital and Tsurugaya Open Hospital in Sendai.

Specimens were fixed in $10 \%$ formalin solution, Zamboni's fixative, Bouin's fixative or $4 \%$ paraformaldehyde, and were dehydrated and embedded in paraffin. One to several representative paraffin blocks including tumor tissues in each case were prepared for histological and immunohistochemical examinations.

Blocks were cut into $2.5 \mu \mathrm{m}$-thick serial sections for histological and histochemical examinations.

Histology. Specimens were stained with hematoxylin and eosin, the Grimelius method for AP cells (Grimelius et al. 1976), Fontana-Masson for AF cells and PAS-alcian blue ( $\mathrm{pH}$ $2.5)$.

Histological classification of gastric carcinoma and the definition of early gastric carcinoma were made according to the General Rules for the Gastric Cancer Study in Surgery and Pathology in Japan (Jap. Res. Soc. for Gastric Cancer 1981).

Immunohistochemistry for brain-gut hormones. Immunohistochemical stains for braingut hormones were performed by the peroxidase anti-peroxidase (PAP) method (Sternberger et al. 1970; Taylor 1978) and an indirect method (Taylor 1978). The indirect method was used for only gastrin. The first (specific) and the second antibodies and their dilution used were as follows: Guinea-pig anti-gastrin (GP-1305) $1: 150$, rabbit anti-glicentin $\mathrm{C}^{\prime}$-terminal (R-4804) $1: 100$, rabbit anti-motilin (R-1105) $1: 100$, rabbit anti-VIP (vasoactive intestinal polypeptide) (R-501) 1:100, rabbit anti- $\alpha$-endorphin (R-3404) 1:40 and rabbit anti- $\beta$ endorphin (R-5803) 1:40, all of which were generously offered by Prof. N. Yanaihara; rabbit anti-somatostatin (Lot. 1039) $1: 300$ and rabbit anti-ADH (Lot. 701) $1: 300$ given from Dr. K. Mouri ; and rabbit anti-somatostatin (JG-1) $1: 150$ available from the Japan Immunoresearch Laboratories Co., Ltd., Tokyo. The biochemical specificities of antibodies were confirmed by Yanaihara, N. et al. (1979, 1980, 1981), Yanaihara, C. et al. (1980a, b), Ibata et al. (1980), Mouri and Maruyama (1980) and Nishino et al. (1981). The second antisera of swine anti-rabbit immunoglobulins (Z196) $1: 40$, rabbit anti-guinea-pig immunoglobulins/HRP (P141) 1:40 and PAP, rabbit (Z113) 1:80 were obtained from Dakopatts, Denmark.

The following tissues were used as positive controls : normal tissue of the pancreas for the reactions of glicentin and somatostatin; normal antral mucosa of the stomach for gastrin; tumor tissue of VIP-producing pheochromocytoma for VIP; normal tissue of the pituitary for $\mathrm{ADH}$ and $\alpha$ - and $\beta$-endorphins.

The negative control for the specificity of the tissue reaction was tested with nonimmune rabbit or guinea-pig serum as the first layer. After reaction the cells with brownish 
cytoplasm and without staining of nuclei were adopted as positive.

Ultrastructural study. Ultrastructural studies were carried out on 2 cases of carcinoid tumor and a case of carcinoid-like carcinoma. Specimens were fixed in $2.5 \%$ glutaraldehyde and $2 \%$ paraformaldehyde at $\mathrm{pH} 7.4$ and embedded in Epon 812 by routine techniques. Thin sections of 600-800 $\AA$ were stained with uranyl acetate and lead citrate and examined with a JEOL 100B electron microscope.

\section{RESUlts}

\section{Argyrophil and argentaffin cells in gastric carcinoma}

Histological types of gastric carcinoma positive with AP and AF reactions and immunoperoxidase stains for brain-gut hormones are shown in Table 1. AP cells were demonstrated in $38(44 \%)$ out of 87 gastric carcinomas including 3 carcinoid tumors. AF cells appeared in $18(21 \%)$ and endocrine cells in $13(14 \%)$. AP cells were contained in all histological types, while AF cells were absent in papillary adenocarcinoma and undifferentiated carcinoma.

\section{Endocrine cells in gastric carcinoma}

The results of the immunoperoxidase stain for brain-gut hormones and silver stains are listed in Table 2 . The incidence of carcinoma with endocrine cells was $6(37 \%)$ out of 18 cases containing both AP and AF cells and $7(36 \%)$ out of 20 cases with AP cells alone. All cases with endocrine cells had AP cells. All with negative silver reaction had no endocrine cells. The clinicopathological details of 13 cases with endocrine cells are shown in Table 3 . The patients were 40 to 75

TABLE 1. Histological type of gastric carcinoma with positive argyrophil, argentaffin and immunostain reactions

\begin{tabular}{lcrrr}
\hline \multirow{2}{*}{ Histological types } & \multirow{2}{*}{ Number of cases } & \multicolumn{3}{c}{ Positive with } \\
\cline { 3 - 5 } & & AP & AF & IM \\
\hline Papillary adenocarcinoma (pap) & 8 & 2 & 0 & 1 \\
Tubular adenocarcinoma & & & & \\
Well differentiated (tub ${ }^{1}$ ) & 15 & 5 & 3 & 2 \\
$\quad$ Moderately differentiated (tub $\left.{ }^{2}\right)$ & 10 & 4 & 2 & 3 \\
Poorly diff. adenocarcinoma & & & & \\
Medullary type (por, med) & 10 & 4 & 1 & 1 \\
Scirrhous type (por, sci) & 27 & 12 & 5 & 1 \\
Mucinous adenocarcinoma (muc) & 7 & 4 & 3 & 2 \\
Signet ring cell carcinoma (sig) & 5 & 2 & 2 & 0 \\
Undiff. carcinoma (ud) & 2 & 2 & 0 & 2 \\
Carcinoid tumor (cd) & 3 & 3 & 2 & 1 \\
$\quad$ Total & 87 & 38 & 18 & 13 \\
$\quad \%$ ) & & $(43.7)$ & $(20.7)$ & $(14.3)$ \\
\hline
\end{tabular}

AP, argyrophil reaction (Grimelius); AF, argentaffin reaction (Fontana-Masson) ;

IM, immunostain. 
TABLE 2. Comparison of argyrophil and argentaffin cells to immunostain for brain-gut hormones

\begin{tabular}{ccccc}
\hline \multirow{2}{*}{ Argyrophil } & Argentaffin & \multirow{2}{*}{$\begin{array}{c}\text { Total } \\
\text { number of cases }\end{array}$} & \multicolumn{2}{c}{ Immunostain } \\
\cline { 4 - 5 } & & 18 & $6(33.3)$ & $12(66.7)$ \\
+ & + & 20 & $7(35.0)$ & $13(65.0)$ \\
+ & - & 0 & 0 & 0 \\
- & + & 49 & $0(0)$ & $49(100.0)$ \\
- & - & 87 & $13(14.9)$ & \\
Total & & & & \\
\hline
\end{tabular}

years of age and composed of 10 males and 3 females. Eleven cases were of advanced carcinoma and 2 were early. There was no relationship of the appearance and localization of endocrine cells to the histological type or the depth of invasion. The results of immunoperoxidase stains for gastrin, motilin, glicentin, somatostatin, $\beta$-endorphin, $\alpha$-endorphin, VIP and $\mathrm{ADH}$ in relation to $\mathrm{AP}$ and $\mathrm{AF}$ cells are shown in Table 4. Glicentin was positive in 10 cases, somatostatin in 7 , motilin in $3, \beta$-endorphin in 2 and gastrin in one. The mode of immunoreactivity in the individual cases are shown in Table 5. Positive stain for only glicentin was found in 4 cases, and for both glicentin and somatostatin in 3. Six other types of positive stain were observed in one case each. No single cell simultaneously positive for two or more brain-gut hormones was found in serial sections. Evidence of positive argyrophil reaction in endocrine cells was also observed.

TABLE 3. Gastric carcinama with positive

\begin{tabular}{rcccclc}
\hline Case & Age & Sex & Location* & Size (cm) & $\begin{array}{c}\text { Histological } \\
\text { type }\end{array}$ & $\begin{array}{c}\text { Depth of } \\
\text { Invasion }\end{array}$ \\
\hline 1 & 56 & M & A & $3.5 \times 3.0$ & ud & $\mathrm{sm}$ \\
2 & 63 & M & A & $5.2 \times 2.5$ & tub $^{2}$ & $\mathrm{sm}$ \\
3 & 40 & F & M & $4.0 \times 4.0$ & tub $^{2}$ & $\mathrm{~s}$ \\
4 & 53 & M & A & $4.5 \times 4.0$ & $\mathrm{~cd}^{2}$ & $\mathrm{~s}$ \\
5 & 65 & M & A & $4.0 \times 2.0$ & ud & pm \\
6 & 67 & M & AM & $7.0 \times 7.6$ & pap & $\mathrm{s}$ \\
7 & 69 & M & A & $6.8 \times 3.7$ & tub & pm \\
8 & 75 & M & A & N.D. & tub & $\mathrm{s}$ \\
9 & 73 & M & A & $9.0 \times 8.0$ & muc & $\mathrm{s}$ \\
10 & 40 & F & C & $10.2 \times 8.0$ & por, sci & $\mathrm{s}$ \\
11 & 53 & M & MA & $6.0 \times 6.0$ & por, med & $\mathrm{s}$ \\
12 & 69 & F & MA & $7.0 \times 10.0$ & muc & $\mathrm{s}$ \\
13 & 69 & M & A & $9.0 \times 10.0$ & tub & $\mathrm{s}$ \\
\hline
\end{tabular}

AP, argyrophil reaction; AF, argentaffin reaction; GLI, glicentin; SOMT, soma LIM, localization of immunostain positive cells.

* The stamach is separated into the upper (C), middle (M) and lower (A) portions curvature. 
TABLE 4. Total number of positive immunostain cases in gastric carcinama in relation to argyrophil and argentaffin cells

\begin{tabular}{|c|c|c|c|c|}
\hline & $\begin{array}{l}\text { Argyrophil } \\
\text { Argentaffin }\end{array}$ & $\begin{array}{l}+ \\
+\end{array}$ & $\begin{array}{l}+ \\
-\end{array}$ & Total \\
\hline \multicolumn{2}{|c|}{ Number of cases } & 6 & 7 & 13 \\
\hline \multicolumn{5}{|c|}{ Immunostain for } \\
\hline \multirow{8}{*}{ Positive } & Gastrin & 1 & 0 & 1 \\
\hline & Motilin & 2 & 1 & 3 \\
\hline & Glicentin & 5 & 5 & 10 \\
\hline & Somatostatin & 2 & 5 & 7 \\
\hline & $\beta$-Endorphin & 0 & 2 & 2 \\
\hline & $\alpha$-Endorphin & 0 & 0 & 0 \\
\hline & VIP & 0 & 0 & 0 \\
\hline & $\mathrm{ADH}$ & 0 & 0 & 0 \\
\hline
\end{tabular}

The frequency of these cells varied with individual cases. Endocrine cells were relatively small in number in most cases, but somatostatin cells in a carcinoid tumor were exceptional and distributed diffusely and densely.

\section{Localization of endocrine cells and tumor histology}

Endocrine cells within the tumor were variable in appearance and number.

Tubular adenocarcinoma. Endocrine cells were demonstrated in 5 out of 25 cases. In case No. 7, carcinoma cells positive for glicentin, somatostatin, gastrin immunostain for brain-gut hormones

\begin{tabular}{ccllc}
\hline AP & AF & Positive immunostain & LIM & $\begin{array}{c}\text { BS } \\
(\mathrm{mg} / 100 \mathrm{ml})\end{array}$ \\
\hline+ & - & SOMT & $\mathrm{sm}$ & 75 \\
+ & + & GLI +SOMT & $\mathrm{sm}$ & 82 \\
+ & - & GLI +SOMT & $\mathrm{sm}$ & 71 \\
+ & - & GLI +SOMT $+\beta$-END & $\mathrm{pm}$ & 88 \\
+ & - & -END & $\mathrm{pm}$ & 83 \\
+ & - & GLI + SOMT & $\mathrm{pm}$ & 88 \\
+ & + & GLI + SOMT + MOT + GAS & $\mathrm{pm}$ & 101 \\
+ & + & GLI & $\mathrm{s}$ & 160 \\
+ & - & GLI + SOMT + MOT & $\mathrm{pm}$ & $\mathrm{N} . \mathrm{D}$. \\
+ & + & GLI & $\mathrm{sm}$ & 91 \\
+ & + & MOT & $\mathrm{m}, \mathrm{sm}$ & 107 \\
+ & + & GLI & $\mathrm{m}, \mathrm{sm}$ & 109 \\
+ & - & GLI & $\mathrm{sm}$ & 117 \\
\hline
\end{tabular}

tostatin; MOT, motilin; GAS, gastrin ; $\beta$-END, $\beta$-endorphin; BS, blood sugar ;

by drawing lines between the corresponding trisectional points on the greater and lesser 
TABle 5. Positive immunostain for brain-gut hormones in the individual cases

\begin{tabular}{lc}
\hline \multicolumn{1}{c}{ Immunostain } & Number of cases \\
\hline GLI only & 4 \\
GLI + SOMT & 3 \\
GLI + SOMT + MOT & 1 \\
GLI + SOMT + $\beta$-END & 1 \\
GLI + SOMT + MOT + GAS & 1 \\
SOMT only & 1 \\
MOT only & 1 \\
$\beta$-END only & 1 \\
\multicolumn{1}{c}{ Total } & 13 \\
\hline
\end{tabular}

GLI, glicentin ; SOMT, samatostatin ; MOT, motilin ; GAS, gastrin ; $\beta$-END, $\beta$-endorphin.

and motilin were demonstrated (Figs. 1, 2 and 3). Both glicentin and gastrin cells were confirmed to be argyrophil by a serial slides of hematoxylin and eosin, Grimelius and immunoperoxidase stains. Somatostatin cells were weakly argyrophil and motilin cells were negative for argyrophil nor argentaffin reactions.

Poorly differentiated adenocarcinoma. Endocrine cells were demonstrated in 2 out of 37 cases. In case No. 10 of the scirrhous type mixed with signet-ring cells, glicentin cells were confirmed to be argyrophil in the adjacent slide of serial

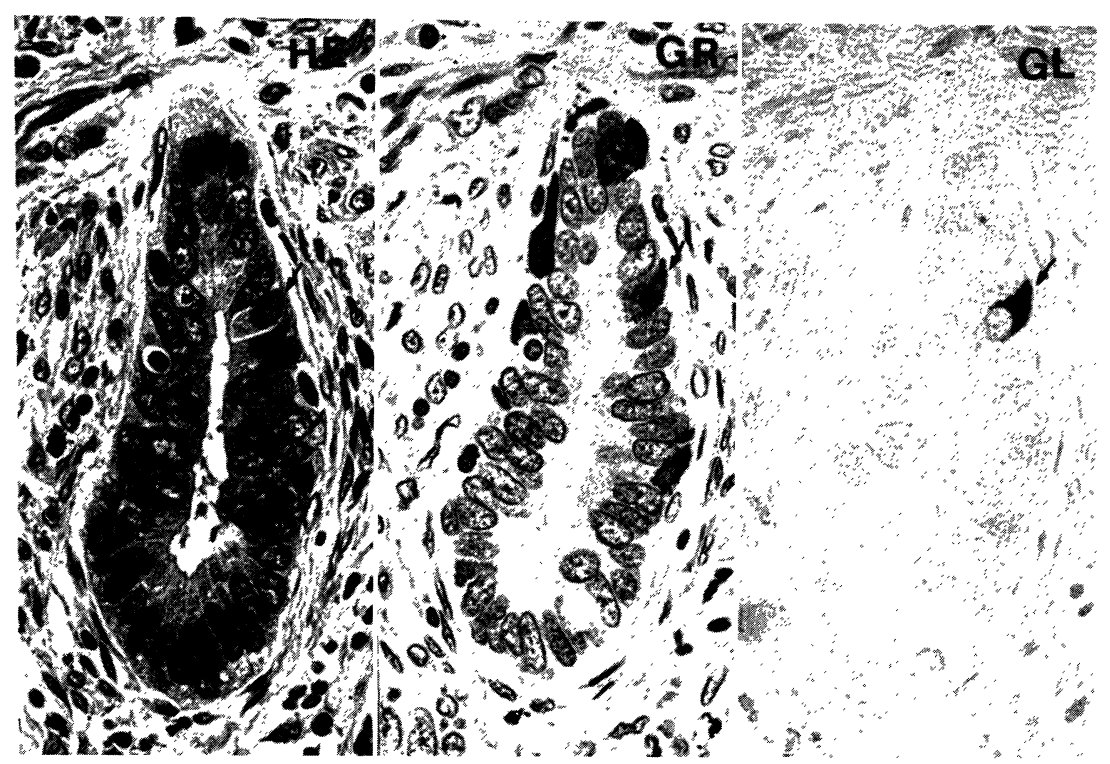

Fig. 1. Well differentiated tubular adenocarcinoma. Arrows indicate the same cell in three serial sections stained with hematoxylin and eosin (HE), Grimelius (GR) and glicentin by the PAP method (GL). Glicentin cells are argyrophilic. (Case $7 . \times 400$ ) 
section (Fig. 4). In the medullary type of case No. 11, motilin cells were demonstrated (Fig. 5), and negative for argyrophil and argentaffin reactions.

Mucinous adenocarcinoma. Endocrine cells were demonstrated in 2 out of 7 cases. In case No.9, carcinoma cells positive for glicentin, somatostatin and motilin were demonstrated. In case No. 12, the immunostain was successful only for glicentin.

Carcinoid-like carcinoma in undifferentiated carcinoma. In case No. 1, tumor cells were significantly pleomorphic and atypic. Carcinoma cells were mostly positive with Grimelius stain and negative with Fontana-Masson stain. Only somatostatin cells were demonstrated (Fig. 6). Electron microscopically, round secretory granules, $150-200 \mathrm{~nm}$ in diameter, and pleomorphic granules, 300-400 $\mathrm{nm}$ in diameter, were observed (Figs. 7A, 7B). In case No. 5, tumor cells were pleomorphic and arranged in an alveolar pattern focally with a rosette structure (Fig. 8). Many AP cells and a few $\beta$-endorphin cells were demonstrated. These cases were regarded to be compatible with carcinoid-like carcinoma or endocrine cell carcinoma.

Carcinoid tumor. Typical carcinoid tumors were detected in 3 cases. The majority of the tumor cells were AP in all 3 cases and AF in 2 cases. A tumor of case No. 4 located in the antrum was composed of small and uniform cells arranged in alveolar, trabecular, ribbon-like and solid structures consistent with mixed type (Soga et al. 1971) (Fig. 9). Many somatostatin cells and a few $\beta$ -

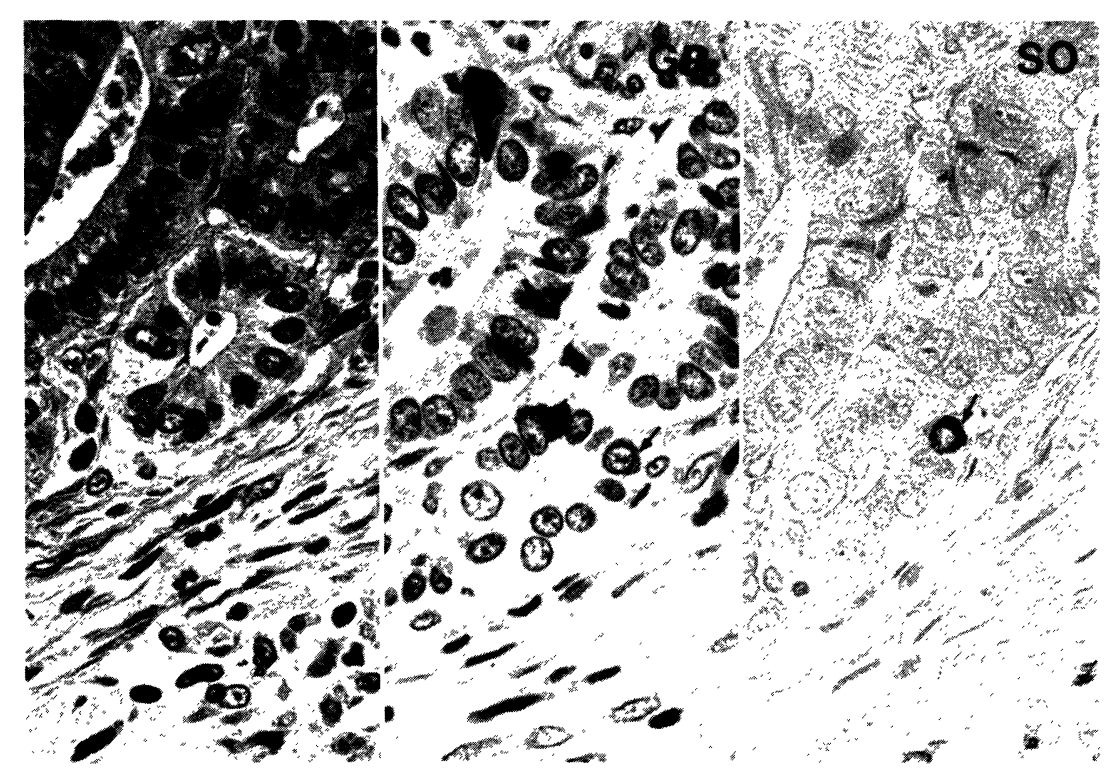

Fig. 2. Well differentiated tubular adenocarcinoma. Arrows indicate the same cell in three serial sections stained with hematoxylin and eosin (HE), Grimelius (GR) and somatostatin by the PAP method (SO). Somatostatin cells are weakly argyrophilic. (Case 7. $\times 400)$ 


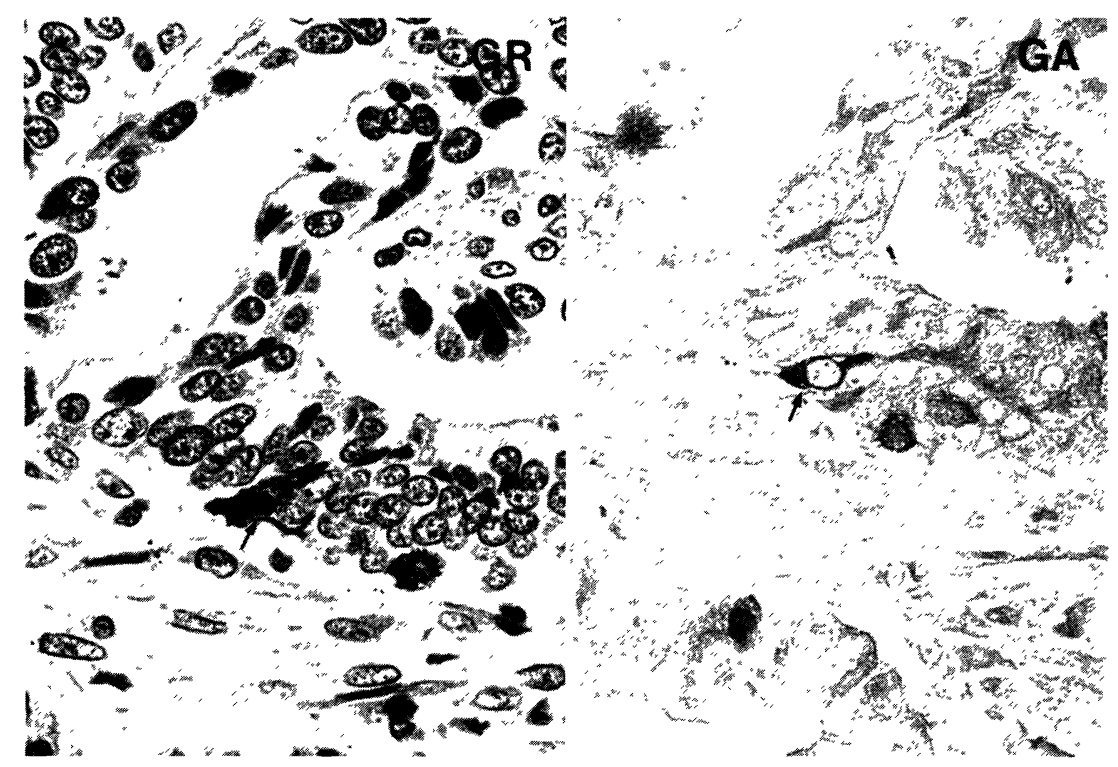

Fig 3. Well differentiated tubular adenocarcinoma. Arrows indicate the same cell in two serial sections stained with Grimelius (GR) and gastrin by the indirect method (GA). Gastrin cells are argyrophilic (Case $7 \times 400)$

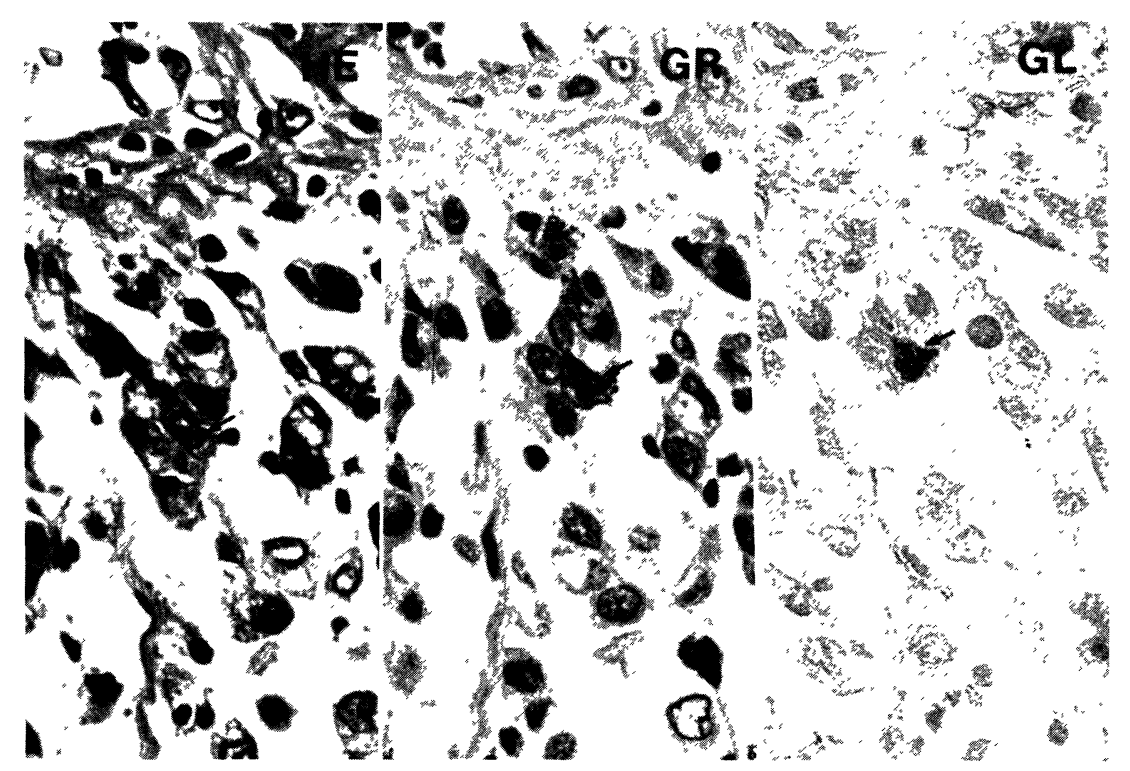

Fig. 4. Poorly differentıated adenocarcinoma of scirrhous type with focal signet-ring cell carcinoma. Arrows indicate the same cell in three serial sections stained with hematoxylin and eosin (HE), Grimelıus (GR) and glicentin by the PAP method (GL). Glicentin cells are argyrophilıc. (Case 10. $\times 400)$ 




Fig. 5. Poorly differentiated adenocarcinoma, medullary type. Tumor cells are small in size and oval or spindle in shape with hyperchromatic nuclei. These findings are consistent with carcinoid-like carcinoma. A few carcinoma cells show positive immunoperoxidase stain for motilin (MO), but are negative for argyrophil and argentaffin stains. (Case $11 . \mathrm{HE} \times 400, \mathrm{MO} \times 400$ )

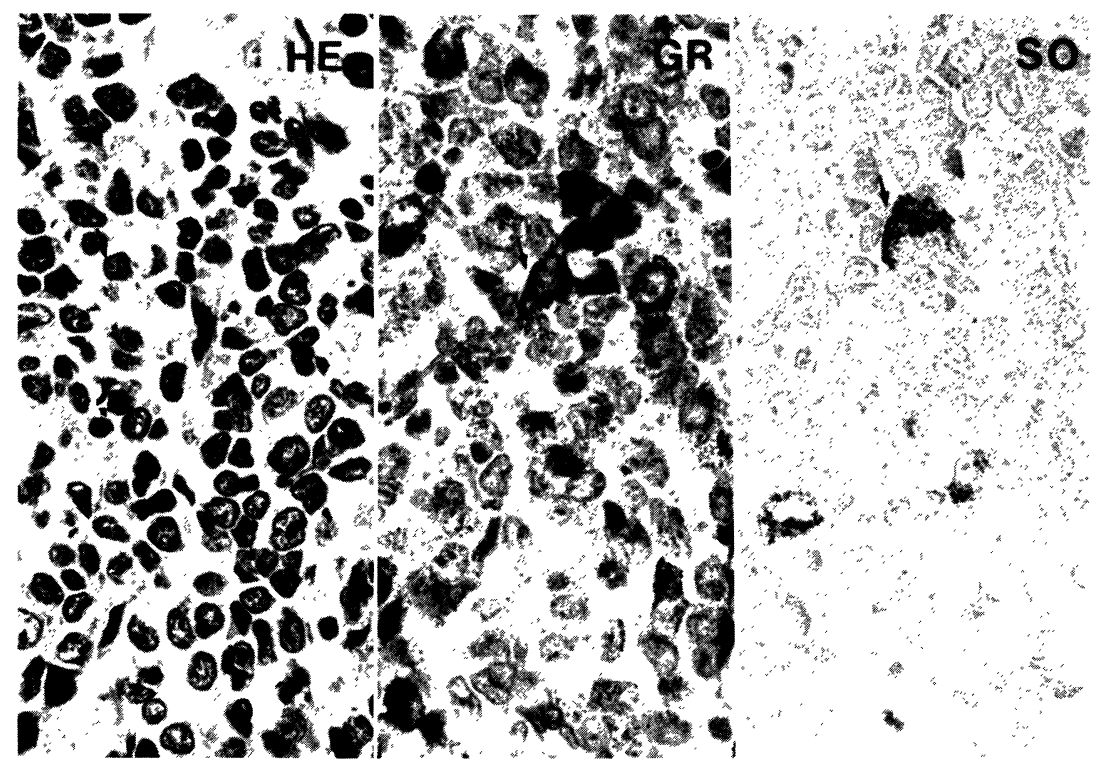

Fig. 6. Carcinoid-like carcinoma. Tumor cells are pleomorphic and show marked cellular atypism. Most of the tumor cells are positive with Grimelius stain. Arrows indicate the same cell in three serial sections stained with hematoxylin and eosin (HE), Grimelius (GR) and somatostatin by the PAP method (SO). Somatostatin cells are argyrophilic. (Case $1 . \times 400$ ) 


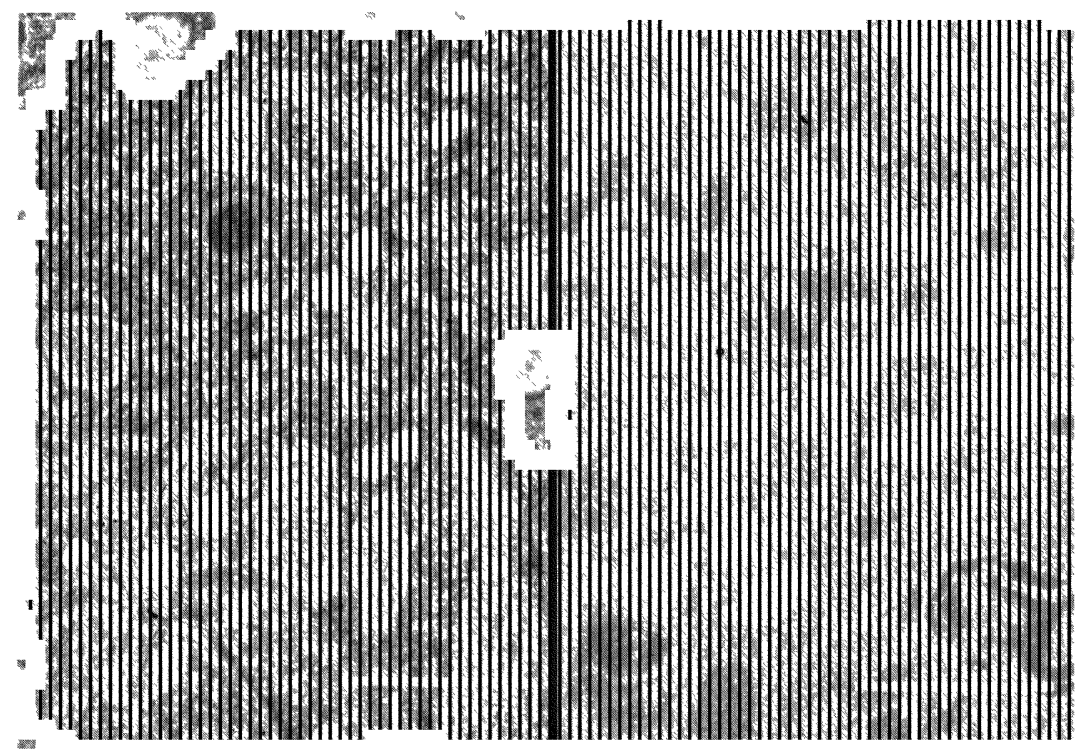

Fig. 7. Electron microscopically round secretory granules, 150-200 $\mathrm{nm}$ in diameter (A), and pleomorphic granules, $300-400 \mathrm{~nm}$ in diameter (B) are observed in the cytoplasm. A part of carcinoid-like carcinoma in Case $1 .(\times 10,000)$

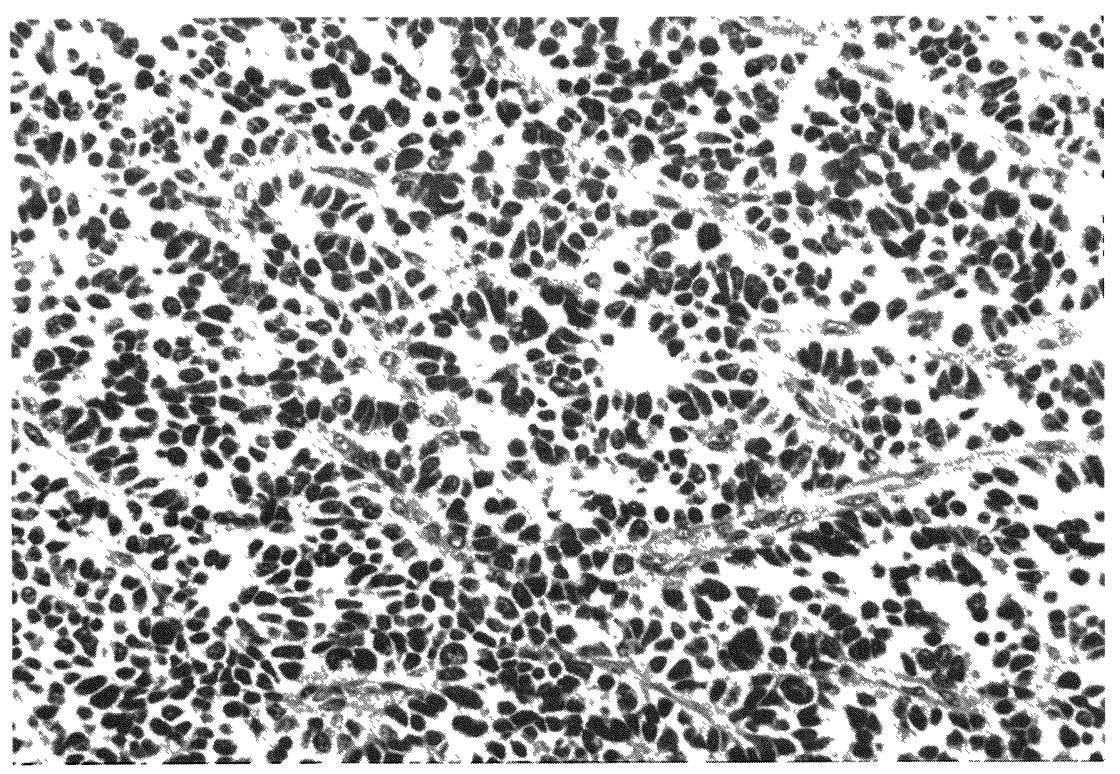

Fig. 8. Undifferentiated carcinoma. The tumor cells show pleomorphism and alveolar patterns with focally rosette structure. (Case 5. hematoxylin and eosin $\times 200$ ) 


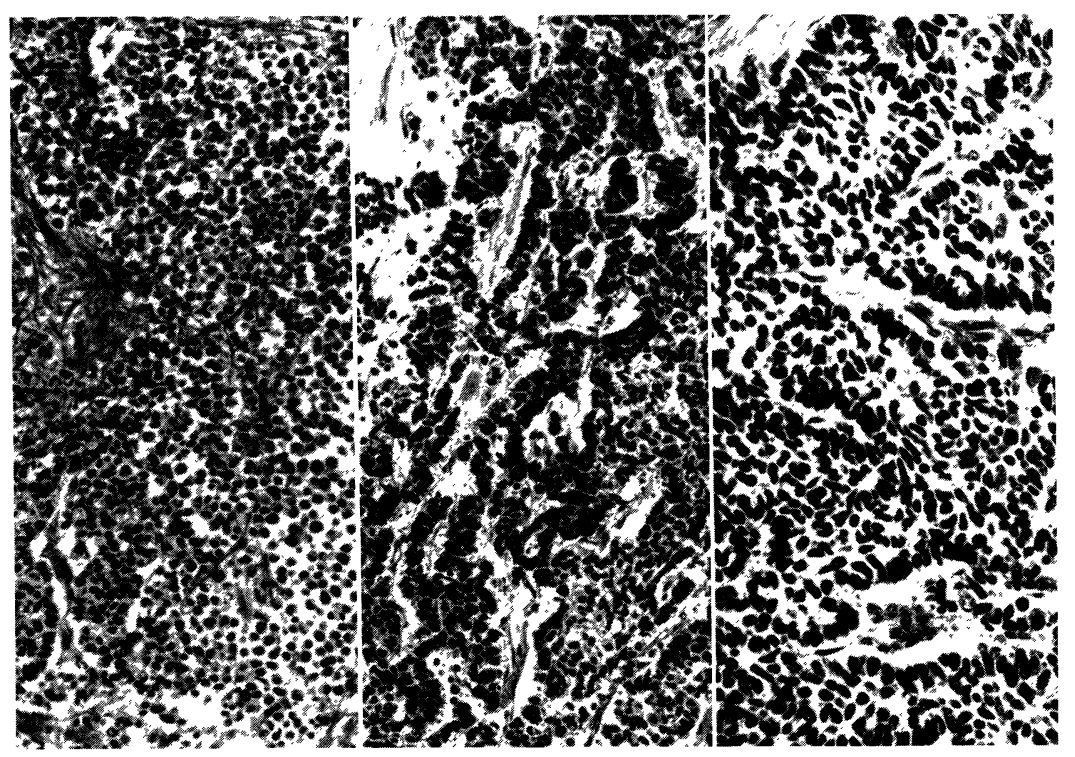

Fig. 9. Carcinoid tumor. The tumor is composed of small and uniform tumor cells with alveolar (left), trabecular and ribbon-like (middle) and solid arrangement (right). (Case 4. hematoxylin and eosin $\times 400$ )

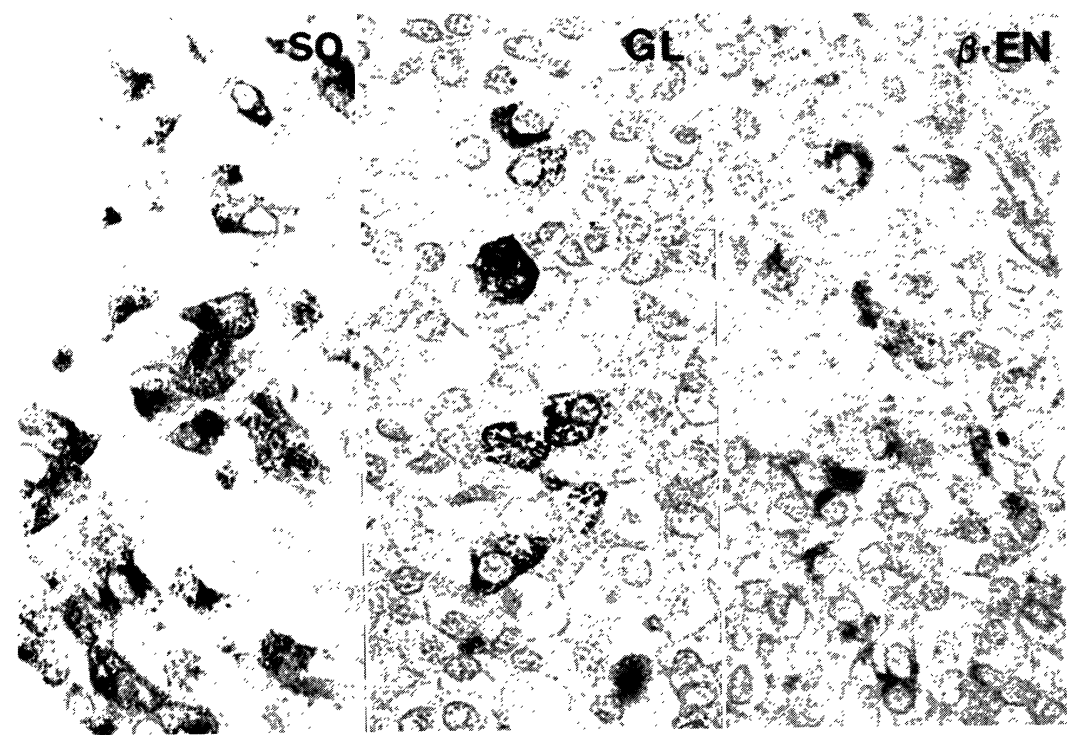

Fig. 10. Carcinoid tumor. The tumor cells arranged in an alveolar pattern show diffusely positive reaction for somatostatin (SO), focally positive for glicentin (GL) and irregularly positive for $\beta$-endorphin $(\beta-\mathrm{EN})$ by the PAP method. (Case $4 . \times 400$ ) 
endorphin cells were demonstrated in only a part of the alveolar pattern (Fig. 10). Electron microscopically, secretory granules, $200-250 \mathrm{~nm}$ in diameter, were observed in the cytoplasm. Two other cases were positive with silver reaction but negative for gastrin, glicentin, somatostatin, endorphins, VIP and ADH. Electron microscopical examinations performed on one of these two cases revealed secretory granules, $100-200 \mathrm{~nm}$ in diameter.

\section{Discussion}

The appearance of AP and AF cells in gastric carcinoma was first described by Hamperl (1927) and reported by several authors (Azzopardi and Pollock 1963 ; Tahara et al. 1975, 1982 ; Nagata 1977) with various incidences. With respect to the histological type of gastric carcinoma, Tahara et al. (1975) observed AP cells in $20.7 \%$ of poorly differentiated adenocarcinoma and undifferentiated carcinoma. No definite relationship between the appearance of AP cells and histological types of gastric carcinoma was, however, obtained by other investigators (Kubo and Watanabe 1971; Watanabe 1972; Nagata 1977). In the present study AP cells appeared in three histologically different carcinomas ; well differentiated tubular adenocarcinoma (case No. 7), and poorly differentiated adenocarcinoma (cases No. 2 and No. 8) and undifferentiated carcinoma (cases No. 1 and No. 5) which was called as diffuse argentaffinoma (Kubo and Watanabe 1971). If these AP cells are consistent with endocrine cells, certain hormones secreted by these cells should be demonstrated. In gastric carcinoma, gastrin cells were domonstrated by Tahara et al. (1975, 1980) and Nagata (1977). Prade et al. (1982) made a detailed immunohistochemical study of a gastric adenocarcinoma with argyrophil cells. About 30 percent of the M2-positive cells stained strongly with an antigastrin serum as well as with the argyrophilic reagents.

Tahara et al. (1982) confirmed 9 cases producing polypeptides such as gastrin, somatostatin and glucagon among 16 cases of argyrophil carcinoma out of 59 gastric scirrhous carcinoma. In our study, glicentin, somatostatin, motilin, gastrin and $\beta$-endorphin cells were demonstrated (Tables 4 and 5). It is interesting that motilin cells originally specified to the small intestinal mucosa were demonstrated in 3 cases of gastric carcinoma. This may suggest a relationship between the pathogenesis of gastric carcinoma and intestinal metaplasia. Glicentin, somatostatin and gastrin cells in carcinoma tissue were argyrophil with the Grimelius stain like endocrine cells in the normal gastrointestinal mucosa (Grimelius et al. 1976; Lechago 1978; Solcia et al. 1979).

With regard to the origin of endocrine cells occurring in gastric carcinoma, Tahara et al. (1980, 1982) and Nagata (1977) explained that they originate from the tumor cells derived from the endodermal stem cells with multipotentiality. Soga et al. (1971), however, stressed that endocrine cells in carcinoma tissues are non-neoplastic because of their negligible atypism. Azzopardi and Pollock (1963) also doubted whether endocrine cells in metastatic carcinoma tissue in 
lymph nodes are neoplastic or not. Concerning this our results were also nonconclusive, but it should be emphasized that some of these cells apparently showed considerable atypism. The problems of neoplastic endocrine cells will be resolved in near future.

Recently the definition of carcinoid tumors has been changed. This tumor with a definitive histological pattern is a kind of functioning tumors which secrete various peptide hormones and amines. This has been corroborated by certain investigators (Hirata et al. 1976; Wilander et al. 1979; Dayal et al. 1980; Marcus et al. 1980). We could immunohistochemically demonstrate the activity of somatostatin, glicentin and $\beta$-endorphin in one out of 3 gastric carcinoid tumors.

Auböck and Höfler (1983) proposed two ways in histogenesis of gastrointestinal carcinoid tumor; the one from intestinal epithelial cells and the other from disseminated extraepithelial, intraneural endocrine cells. Concerning the former way of development, a carcinoid-like carcinoma has been documented. There are two types in it. One is called composite type carcinoid (Gibbs 1963 ; Bates and Betler 1967). The other carcinoid-like carcinoma is undifferentiated carcinoma classified by Matsuzaka (1976). This type is also called endocrine cell carcinoma or oat cell carcinoma (Eimoto and Hayakawa 1980) and lies between carcinoid tumor and carcinoma. As to be asserted by Tahara et al. (197.5, 1982), a spectrum from adenocarcinoma to carcinoid tumor of the stomach was demonstrated in our study. Cox and Pierce (1982) successfully demonstrated evidence for the endodermal origin of the endocrine cells in an adenocarcinoma of the colon of the rat by subcutaneous transplantation of single carcinoma cell. We have agreed to hypothesis of Soga (1982) and Tahara et al. (1982) that both carcinoma and a carcinoid tumor commonly originate from totipotent stem cells of endodermal origin in the gastric mucosa.

\section{Acknowledgments}

We thank Prof. N. Yanaihara (Shizuoka College of Pharmacy) and Dr. T. Mouri (Department of Internal Medicine, Tohoku University School of Medicine) for their generous offer of special antisera of brain-gut hormones.

\section{References}

1) Auböck, L. \& Höfler, H. (1983) Extraepithelial intraneural endocrine cells as starting-points for gastrointestinal carcinoids. Virchows Arch. A, 401, 17-33.

2) Azzopardi, J.G. \& Pollock, D.J. (1963) Argentaffin and argyrophil cells in gastric carcinoma. J. Path. Bacteriol., 86, 443-451.

3) Bates, H.R. \& Belter, L.F. (1967) Comparative carcinoid tumor (argentaffinomaadenocarcinoma) of the colon: Report of two cases. Dis. Col. \& Rect., 10, 467-470.

4) Cox, W.F. \& Pierce, G.B. (1982) The endodermal origin of the endocrine cells of adenocarcinoma of the colon of the rat. Cancer, 50, 1530-1538.

5) Dayal, Y., O'Briain, D.S., DeLellis, R.A. \& Wolfe, H.J. (1980) Carcinoid tumors in gastrointestinal and extraintestinal sites; a comparative study of polypeptide hormone profiles. Regulatory Peptide, 1, Suppl. 1, 22. 
6) Eimoto, T. \& Hayakawa, H. (1980) Oat cell carcinoma of the stomach. Path. Res. Pract., 168, 229-236.

7) Gibbs, N.M. (1963) The histogenesis of carcinoid tumors of the rectum. J. clin. Path., 16, 206-214.

8) Grimelius, L., Capella, C., Buffa, R., Usellini, L. Frigerio, B. \& Fontana, P. (1976) Cytochemical and ultrastructural differentiation of enteroglucagon and pancreatic type glucagon cells of the gastrointestinal tract. Virchows Arch. B, 20, 217-228.

9) Hamperl, H. (1927) Über die "gelben (chromaffin)" Zellen in gesunden und kranken Magen-darmschlauch. Virchows Arch., 266, 509-548.

10) Hirata, Y., Sakamoto, N., Yamamoto, H., Matsukura, S., Imura, H. \& Okada, S. (1976) Gastric carcinoid with ectopic production of $\mathrm{ACTH}$ and $\beta-\mathrm{MSH}$. Cancer, 37, 377385.

11) Ibata, Y., Watanabe, K., Kinoshita, H., Kubo, S., Sano, Y., Sakura, N., Yanaihara, C. \& Yanaihara, N. (1980) Dopamine and $\alpha$-endorphin are contained in different neurons of the arcuata nucleus of hypothalamus as revealed by combined fluorescence histochemistry and immunohistochemistry. Neurosci. Letters, 17, 185-189.

12) Japanese Research Society for Gastric Cancer (1981) The general rules for the gastric cancer study in surgery and pathology. Jap. J. Surg., 11, 127-139.

13) Kubo, T. \& Watanabe, H. (1971) Neoplastic argentaffin cells in gastric and intestinal carcinomas. Cancer, 27, 447-454.

14) Lechago, J. (1978) Endocrine cells of the gastrointestinal tract and their pathology. Path. Ann., 13, 329-350.

15) Marcus, F.S., Friedman,M.A., Callen, P.W., Churg, A. \& Harbour, J. (1980) Successful therapy of ACTH-producing gastric carcinoid APUD tumors : Report of a case and review of the literature. Cancer, 46, 1263-1269.

16) Matsuzaka, T. (1976) Solid undifferentiated carcinomas of the stomach. A histological study with a supplement search for argyrophil cells. Fukuoka Acta med., 67, 163187.

17) Mouri, K. \& Maruyama, T. (1980) ADH content in neurohypophysis of the rat. Jap. J. Physiol., 42, 84. (in Japanese)

18) Nagata, T. (1977) Gastrin-cells in carcinoma of the stomach. An immunofluorescence study with special reference differentiation and histogenesis. Fukuoka Acta med., 68, 327-348.

19) Nishino, T., Kodaira, T., Shin, S., Imagawa, K., Kumahara, Y., Yanaihara, C. \& Yanaihara, N. (1981) Glucagon radioimmunoassay with use of antiserum to glucagon C'-terminal fragment. Clin. Chem., 27, 1690-1697.

20) Prade, M., Bara, J., Gadenne, C., Bugnel, C., Charpentier, P., Ravazzola, M. \& Caillou, B. (1982) Gastric carcinoma with argyrophilic cells : Light microscopic, electronmicroscopic and immunochemical study. Human Path., 13, 558-592.

21) Soga, J. (1982) Histogenesis of carcinoids in relation to ordinary carcinomas. Acta med. biol., 30, 17-33.

22) Soga, J., Tazawa, K., Aizawa, O., Wada, K. \& Muto, T. (1971) Argentaffin cell carcinoma of the stomach. An atypical carcinoid? Cancer, 28, 999-1003.

23) Solcia, E., Capella, C., Buffa, R., Usellini, L., Frigerio, B. \& Fontana, P. (1979) Endocrine cells of the gastrointestinal tract and related tumors. Pathobiol. Ann., 9, 163-204.

24) Sternberger, L.A., Handy, P.H., Jr., Cuculis, J.J. \& Meyer, H.G. (1970) The unlabeled antibody enzyme method of immunohistochemistry. Preparation and properties of soluble antigen-antibody complex (horseradish peroxidase-antihorseradish peroxidase) and its use in identification of spirochetes. J. Histochem. Cytochem., 18, 315-333.

25) Tahara, E., Haizuka, S., Kodama, T. \& Yamada, A. (1975) The relationship of gastrointestinal endocrine cells to gastric epithelial change with special reference to 
gastric cancer. Acta path. jap., 25, 161-177.

26) Tahara, E., Ito, H., Shimamoto, F., Nakagami, K. \& Iwamoto, T. (1980) Relation of gastric carcinoma to gastrointestinal endocrine cell, especially gastrin production of cancer cells. Igaku No Ayumi, 113, 248-250. (Japanese)

27) Tahara, E., Ito, H., Nakagami, K., Shimamoto, F., Yamamoto, M. \& Sumii, K. (1982) Scirrhous argyrophil cell carcinoma of the stomach with multiple production of polypeptide hormones, amines, CEA, lysozyme and HCG. Cancer, 49, 1904-1915.

28) Taylor, C.R. (1978) Immunoperoxidase techniques. Practical and theoretical aspects. Arch. Path. Lab. Med., 102, 113-121.

29) Watanabe, H. (1972) Argentaffin cells in adenoma of the stomach. Cancer, 30, $1267-1274$.

30) Wilander, E., Grimelius, L., Lndqvist, G. \& Skoog, V. (1979) Polypeptide hormones in argentaffin and argyrophil gastrointestinal endocrine tumors. Amer. J. Path., 96, 519-530.

31) Yanaihara, C., Yanaihara, N., Shimizu, F., Sato, H., Uehara, S. \& Imagawa,K. (1980a) A new type of gastrin derivative and its use for production of central region-specific anti-gastrin sera. Biomed. Res., 1, 242-247.

32) Yanaihara, C., Sakagami, M., Mochizuki, T., Sato, H., Yanaihara, N., Iwanaga, T., Fujii, S. \& Fujita, T. (1980b) Immunoreactive VIP (vasoactive intestinal polypeptide) in canine intestinal mucosa and muscle. Biomed. Res., 1, 449-455.

33) Yanaihara, N. (1980) Immunochemical application of synthetic peptides to studies on the prohormone-hormone system. Biomed. Res., 1, 105-116.

34) Yanaihara, N., Sato, H., Inoue, A., Sakura, N., Sakagami, M., Mochizuki, T., Nakamura, H. \& Yanaihara, C. (1979) Comparative study on distribution of bombesin-, neurotensin- and $\alpha$-endorphin-like immunoreactivities in canine tissues. In: Kinins-II : Biochemistry, Pathophysiology and Clinical Aspects, edited by S. Fujita, Plenum Publishing Corporation, New York, pp. 29-37.

35) Yanaihara, N., Nagai, K., Sato, H., Shimizu, F., Yamaguchi, K. \& Abe, K. (1980) Motilin-like immunoreactivity in porcine, canine, human and rat tissues. Biomed. Res., 1, 76-83.

36) Yanaihara, N., Suzuki, T., Sato, H., Hoshino, M., Okaru, Y. \& Yanaihara, C. (1981) Dibutyryl cAMP stimulation of production and release of VIP-like immunoreactivity in a human neuroblastoma cell line. Biomed. Res., 2, 728-734. 